University of Nebraska - Lincoln

DigitalCommons@University of Nebraska - Lincoln

\title{
An abundant biological control agent does not provide a significant predator subsidy
}

\author{
Philip Tipping \\ USDA-ARS, Philip.tipping@ars.usda.gov \\ Melissa Martin \\ ARM Loxahatchee Wildlife Refuge, Delray Beach, FL \\ Paul Pratt \\ USDA-ARS \\ Min Rayamajhi \\ USDA-ARS \\ Ted Center \\ USDA-ARS
}

Follow this and additional works at: https://digitalcommons.unl.edu/usdaarsfacpub

Tipping, Philip; Martin, Melissa; Pratt, Paul; Rayamajhi, Min; and Center, Ted, "An abundant biological control agent does not provide a significant predator subsidy" (2013). Publications from USDA-ARS / UNL Faculty. 1422.

https://digitalcommons.unl.edu/usdaarsfacpub/1422

This Article is brought to you for free and open access by the U.S. Department of Agriculture: Agricultural Research Service, Lincoln, Nebraska at DigitalCommons@University of Nebraska - Lincoln. It has been accepted for inclusion in Publications from USDA-ARS / UNL Faculty by an authorized administrator of DigitalCommons@University of Nebraska - Lincoln. 


\title{
An abundant biological control agent does not provide a significant predator subsidy
}

\author{
Philip W. Tipping ${ }^{\mathrm{a}, *}$, Melissa R. Martin ${ }^{\mathrm{b}}$, Paul D. Pratt ${ }^{\mathrm{a}}$, Min B. Rayamajhi ${ }^{\mathrm{a}}$, Ted D. Center ${ }^{\mathrm{a}}$ \\ ${ }^{a}$ USDA-ARS, Invasive Plant Research Laboratory, Ft. Lauderdale, FL, USA \\ ${ }^{\mathrm{b}}$ ARM Loxahatchee Wildlife Refuge, Delray Beach, FL, USA
}

\section{H I G H L I G H T S}

- Chemically defended biological control agent experienced low predation.

- Predation effects did not cascade down to producer level.

- Predation events did not increase despite increases in prey populations.

- Hence, an abundant biocontrol agent did not promote a significant predator subsidy.

\section{A R T I C L E I N F O}

\section{Article history:}

Received 2 April 2013

Accepted 23 July 2013

Available online 31 July 2013

\section{Keywords:}

Oxyops vitiosa

Melaleuca quinquenervia

Classical biological control

Herbivory

Food web subsidies

\section{G R A P H I C A L A B S T R A C T}

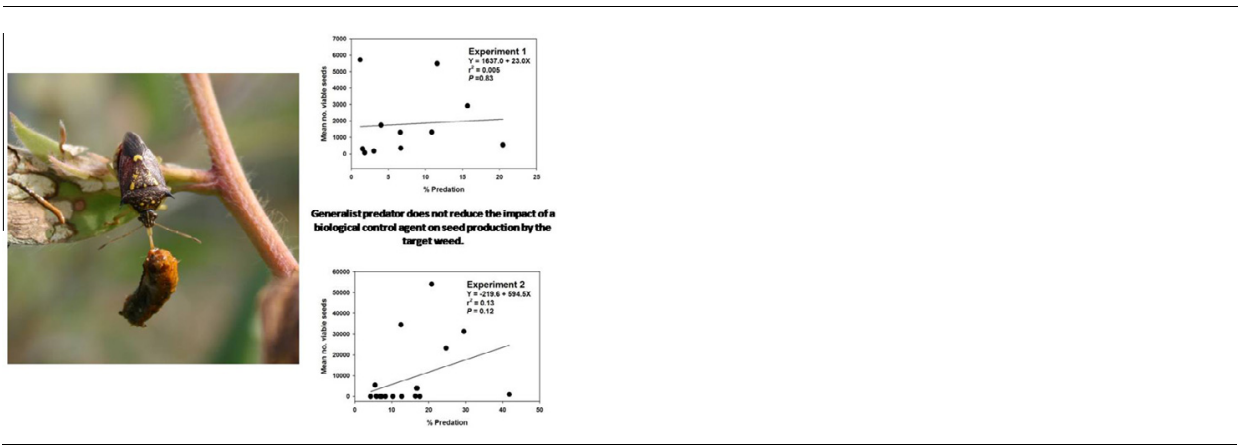

\begin{abstract}
A B S T R A C T
Classical weed biological control agents, regardless of their effectiveness, may provide subsidies to predators and parasites. The chemically defended weevil Oxyops vitiosa Pascoe is a successful agent that was introduced to control the invasive tree Melaleuca quinquenervia. Two consecutive small plot experiments that lasted two and three years, respectively, examined the population dynamics of O. vitiosa while subjected to predation by Podisus mucronatus, a native generalist predator. During this time the estimated mean ( $\pm \mathrm{SE}$ ) percent predation of 0 . vitiosa larvae was $7.2 \pm 1.7 \%$ per sample date in the two year study and $8.4 \pm 0.8 \%$ in the three year study. There was no relationship between the number of larvae per tree and the number that were predated in either experiment. Consumer losses from predation did not cascade down to the producer level and influence any plant variable in either experiment. Time series analysis found no autoregressive processes for predation in either experiment while there were strong first through fourth-order auto-correlations for live larvae in both experiments, indicating the presence of strong trends in prey density. If longevity was a gauge of the relative importance of a predator subsidy, then any provided by 0 . vitiosa was negligible because predation was unlikely to increase over two consecutive sample periods despite increasing prey populations. The benign presence of sustained populations of a biological control agent provides a tailored counter argument to studies that imply inevitable and perilous linkages between introduced agents and community food webs.
\end{abstract}

Published by Elsevier Inc.
* Corresponding author. Address: USDA-ARS Invasive Plant Research Laboratory, 3225 College Ave., Ft. Lauderdale, FL 33314, USA. Fax: +1 9544769169.

E-mail address: philip.tipping@ars.usda.gov (P.W. Tipping).

\section{Introduction}

Classical weed biological control programs aim to reunite exotic invasive weeds with natural enemies in order to re-establish some level of top-down suppression in the invaded range (Mc Fadyen, 1998; Müller-Schärer and Schaffner, 2008). During the process of establishing and acclimating, populations of approved agents are 
subject to demographic, environmental, and genetic processes with outcomes ranging from local extinction to maintenance of outbreak densities (Fauvergue et al., 2012). Predicting these population trajectories and linking them to the target plant population dynamics remains a formidable challenge. The reasons why agents fail to provide effective control are poorly understood but are often attributed to climatic mismatches, population-level compensation of the plant, top-town forces like predation, or bottom up forces like plant quality (Paynter, 2004; Thomas and Reid, 2007; Garren and Strauss, 2009; Center and Dray, 2010; Manrique et al., 2011).

Agents that do establish sustainable populations will inevitably provide temporary or permanent subsidies to generalist predators or stenophagous parasitoids (Paynter et al., 2010; Veldtman et al., 2011). Critics argue that such subsidies influence food web interactions unpredictably, resulting in indirect effects that range from apparent competition to risks to human health (Willis and Memmott, 2005; Pearson and Callaway, 2006). However, a number of studies have observed that food web interactions are generally weak in natural systems (Fagan and Hurd, 1994; Power et al., 1996; Kokkoris et al., 1999). Indirect effects are also widespread in natural systems, unique to their own sets of organisms and communities, and likely to be dynamic processes whose ecological significance will remain open to interpretation (Yodzis, 1988; Polis and Strong, 1996). For example, although Carvalheiro et al. (2008) did document declines in native seed herbivores from apparent competition with an abundant biological control agent, there were also positive effects on native plant abundance. Weighed against these largely theoretical risks are the very concrete and negative consequences to plant, animal, and human communities from the unfettered growth and spread of some exotic plants (Headrick and Goeden, 2001).

The objectives of this study were to (1) characterize the population dynamics of a biological control agent subjected to predation by a generalist predator, (2) determine if consumer losses from predators cascaded down to the producer level, and (3) evaluate the relative importance of the predator subsidy.

\section{Materials and methods}

\subsection{The weed}

Melaleuca quinquenervia (Cav.) S.T. Blake is a tall evergreen tree that has historically occupied tropical to subtropical wetland sites along the eastern coast of Australia (Kaufman and Smouse, 2001). The plant was introduced into southern Florida in 1886 and by 1994 had infested about 200,000 ha (Bodle et al., 1994; Dray et al., 2006). Its invasive attributes are due in part to its reproductive capacity wherein the canopy of a $21 \mathrm{~m}$-tall tree can hold up to 9 million viable seeds (Rayachhetry et al., 2002). In addition to constant propagule pressure via continuous seed rain from a canopyheld seed bank, episodic perturbations like fires cause seed capsules to dehisce and release seeds, usually in one synchronous event. This has led to high density recruitment of M. quinquenervia seedlings, which grow quickly and dominate the area (Van et al., 2002).

Infestations of M. quinquenervia can alter plant and animal community structure and diversity, nutrient storage and cycling, and ecosystem response to disturbance (O'Hare and Dalrymple, 1997; Martin et al., 2009, 2010, 2011). The scale of the problem led to the creation of a long term, integrated management plan using chemical, mechanical, and biological methods which ultimately proved successful in reducing the abundance and impact of the plant (Laroche, 1998). The resulting landscape level reductions in $M$. quinquenervia acreage are credited with reducing the home- range size requirements for the endangered Florida panther, Puma concolor coryi, because of overall improvements to habitat quality (Julian et al., 2012).

\subsection{The biological control agent}

The first agent released against M. quinquenervia was Oxyops vitiosa Pascoe (Coleoptera: Curculionidae) in 1997 (Center et al., 2000). Adults feed on buds and leaves while larvae feed on either leaf surface and consume the leaf tissue through to the cuticle on the other side (Purcell and Balciunas, 1994). This species probably produces 3-5 generations per year in southern Florida, depending on the temperature (Purcell and Balciunas, 1994). Larvae are coated with a thick viscous layer of essential oils sequestered from the plant which provides a potent defense to most predators (Wheeler et al., 2002; Wheeler et al., 2003). This species is considered to be an effective biological control agent at both the individual and plant population levels where it has reduced seed production by up to $99 \%$ and sapling densities by up to $47 \%$ in the field (Tipping et al., 2008; Tipping et al., 2009).

\subsection{The predator}

Podisus mucronatus Uhler (Hemiptera: Pentatomidae) is a common but little studied component of the southern Florida fauna and has been the most apparent predator in areas where 0 . vitiosa has established (Christensen et al., 2011). Costello et al. (2002) described this species in greater detail and tested several nymphal diets for suitability, including one that included 0 . vitiosa. A well studied and presumably similar congener, Podisus maculiventris (Say), has a host range of over 50 prey species, a consistently low attack rate and, unlike other, more specialized penatomid predators like Perillus sp., is found in many habitats (Evans, 1982a; McPherson, 1982; O'Neal, 1988). Podisus maculiventris typically spends more time resting than searching even at higher prey densities (Wiedenmann and O'Neil, 1991). Other ambush-style predators in the Anthocoridae and Lygaeidae are known to conserve energy with relatively long resting periods (Evans, 1976; Cohen, 1984, 1985). Females usually accumulate and begin ovipositing only in the presence of dense aggregations of soft bodied larvae in the Lepidoptera, Hymenoptera (sawflies), and Coleoptera (Warren and Wallis, 1971; Evans, 1982b).

\subsection{Sampling design}

Saplings of $M$. quinquenervia (1-1.5 m height) were planted in two adjacent field plots during December 1999 (experiment 1) and in March 2003 (experiment 2) at the USDA-ARS Invasive Plant Research Laboratory in Ft. Lauderdale, Florida. The prevailing soil type was a Margate fine sand, siliceous hyperthermic Mollic Psammaquent, with less than a $1 \%$ slope. Trees were fertilized and irrigated until they were firmly established. For the purposes of this study, the experimental designs were complete $2 \times 6$ (experiment 1 ) and $2 \times 12$ (experiment 2 ) factorials arranged in a randomized complete block with two irrigation treatments and six or 12 blocks with the tree as the experimental unit located in the center of each $56.25 \mathrm{~m}^{2}$ plot. Hurricane Wilma blew over many trees in experiment 2 on October 24, 2005 which prevented their inclusion in the final analyses.

Irrigation treatments consisted of either natural rainfall or natural rainfall plus continuous irrigation using drippers that provided a mean flow rate of ca $7.5 \mathrm{l} \mathrm{h}^{-1}$ applied to a spot on the soil directly next to the trunk, resulting in continually saturated soils under the dripline of the tree. Precipitation and other abiotic data were captured daily by an automated weather station directly adjacent to the plots. 
Plants were evaluated every 4-6 wk over a 2-yr period (October 2001-October 2003) in experiment 1 and over a 3-yr period (May 2003-May 2006) in experiment 2. Variables monitored during these experiments included the trunk diameter at a marked location equidistant between the soil line and the canopy, the number of terminal branch tips, the numbers of small (instars 1-3), large (instars 4-5), and dead larvae of 0 . vitiosa, and a damage rating based on the percentage of suitable foliage that exhibited larval feeding. The larval damage rating was as follows: (0) no damage, (1) $1-25 \%$ of leaves damaged, (2) $26-50 \%$ damaged leaves, (3) $51-75 \%$ of leaves damaged, (4) $76-99 \%$ of leaves damaged, and (5) $100 \%$ damaged.

Predated 0 . vitiosa larvae exhibited a characteristic deflated, deformed shape from feeding by predacious pentatomids that often dangle their prey off the edge of a leaf while they consume it (Cloutier and Bauduin, 1995). We assumed that all such larvae were killed by $P$. mucronatus. Although it's possible that some larvae were removed by predators and thus were not counted, their sticky outside coating promoted the attachment of their carcasses to the plants. We occasionally witnessed predation by hunting or web spinning spiders of $O$. vitiosa adults, but these and other predators were not counted.

At the end of each experiment the trees were cut down to the soil surface and separated into component portions of leaf, wood, and seed biomass. Subsamples of each component were dried to a constant weight to obtain dry weight biomass. Initial biomass components were estimated before harvesting by using allometry formulas from Rayachhetry et al. (2001). Mean relative growth rates (MRGR: $\mathrm{mg} \mathrm{day}^{-1}$ or $\mathrm{cm} \mathrm{day}^{-1}$ ) were calculated using the formula:

$\operatorname{MRGR}=\frac{\ln W_{2}-\ln W_{1}}{t_{2}-t_{1}}$

where $W_{1}$ and $W_{2}$ are the dry biomass or height at the beginning $\left(t_{1}\right)$ and end $\left(t_{2}\right)$ of the sampling period, and ln is the natural logarithm. Seeds were extracted from capsules, weighed, and the number of seeds produced was estimated by dividing the total seed biomass by the mean weight of an individual seed.

\subsection{Statistical analysis}

Repeated measures analysis of variance was used to measure the effects of predation, herbivory, and irrigation treatments on plant variables (SAS Institute, 1999). Means were transformed using square root transformation for non-normal data or when variances were heterogeneous and then back-transformed for presentation. Herbivore variables that appeared to influence plant variables were further subjected to forward stepwise regression (SAS Institute, 1999). The mean number of predated larvae and live larvae of 0 . vitiosa were calculated for each date and analyzed using a fourth order autoregressive model to test for the independence of errors (no autocorrelation) using the equation:

$\mathrm{Y}_{t}=-a_{1} \cdot \mathrm{Y}_{t-1}+\varepsilon_{t}$

where $\mathrm{Y}$ is the number of predated larvae or total live larvae at time $t$, a is the autoregressive coefficient, and $\varepsilon$ is the regression residual at time $t$. This time series analysis looked for patterns in residuals over time in order to determine if values at a given sample date were influenced by values from previous sample dates. A positive residual under a autoregressive process with positive autocorrelation is more likely to be followed by another positive residual (Freund and Littell, 2000). This outcome might be expected if predation events and prey populations were increasing over time in a biological system. Durban-Watson statistics were generated using PROC AUTOREG (SAS Institute, 1999) for time lags up to four sample dates (Freund and Wilson, 1998).
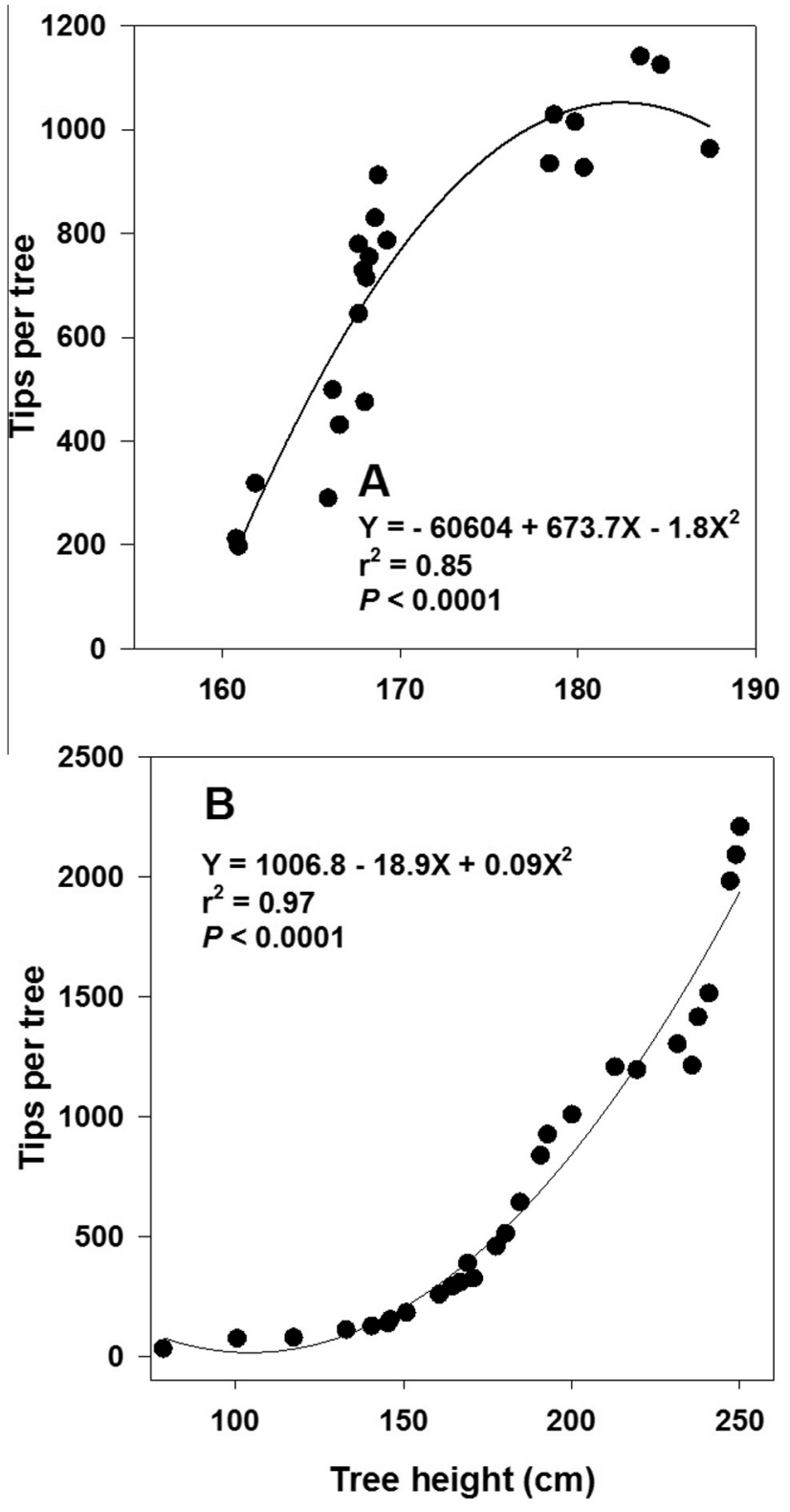

Fig. 1. Relationship between tree height and the number of tips per tree in the first (A) and second (B) experiments.

\section{Results}

Irrigation did not influence percent larval predation $(P=0.57)$ so the data were combined within each experiment. As trees grew in height in both experiments, they produced more branch apices or tips where feeding by 0 . vitiosa was concentrated (Fig. 1). Although increased numbers of tips resulted in fewer 0 . vitiosa per tip in the first experiment (Fig. 2A) and was constant during the second experiment (Fig. 2B), the total number of larvae within a tree increased over the duration in both experiments. There was no relationship between the number of larvae per tree and the number that were predated in either experiment (Fig. 3A and B). Overall, the estimated mean $( \pm \mathrm{SE})$ percent predation of $O$. vitiosa larvae was $7.2 \pm 1.7 \%$ per sample date in experiment 1 and $8.4 \pm 0.8 \%$ in experiment 2 .

Larval predation did not influence any plant variable in the first experiment, including the overall damage rating (Table 1). The damage ratings did predict the MRGR for tree height 

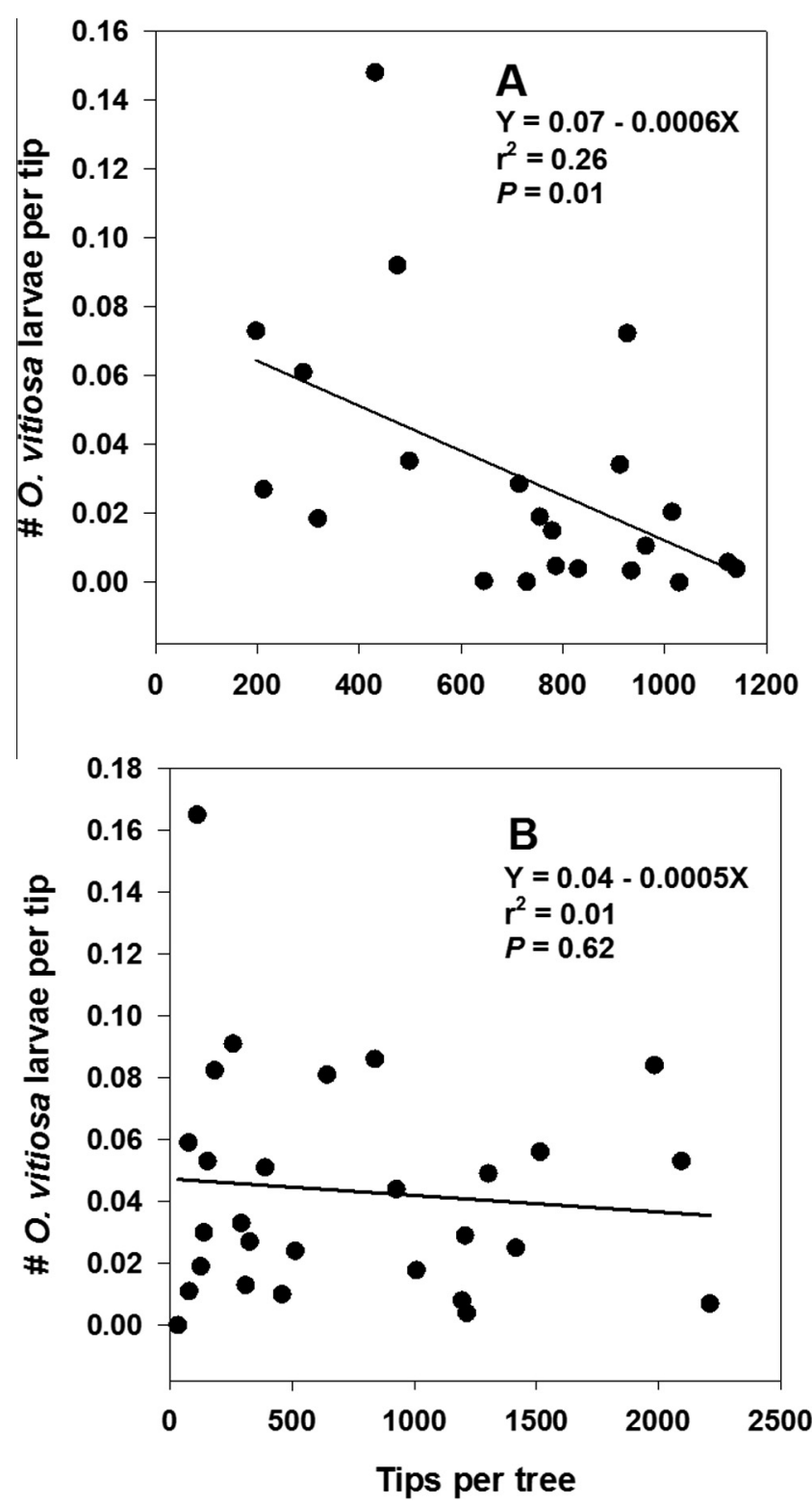

Fig. 2. Relationship between the number of tips per tree and the number of $O$. vitiosa larvae per tip in the first (A) and second (B) experiments.

(Fig. 4A) and the mean seed production per tree (Fig. 4B), but not the MRGR for leaf (Fig. 4C) or wood biomass (Fig. 4D), despite an overall trend of lower MRGR with increasing damage. The same was true in the second experiment whereby predation did not influence the plant damage rating $(P=0.29)$ which, in turn, did predict the MRGR of tree height (Fig. 5A), leaf (Fig. 5B), wood biomass (Fig. 5C), and the mean number of seeds produced per tree (Fig. 5D).

Small and/or large larval prey densities negatively influenced some plant growth variables, including the MRGR for leaf biomass in the first $\left(r^{2}=0.42, P=0.02\right)$ and second $\left(r^{2}=0.43, P=0.06\right)$ experiment (Table 2). In addition, damage ratings increased $\left(r^{2}=0.15, P=0.12\right)$ while seed production decreased $\left(r^{2}=0.24\right.$, $P=0.05)$ with increases in large larval prey densities in experiment 2 (Table 2). No autoregressive processes were present for the number of predated larvae in either experiment (Table 3). At the same time there were strong first through fourth-order autocorrelations for live larvae in both experiments (Table 3 ).
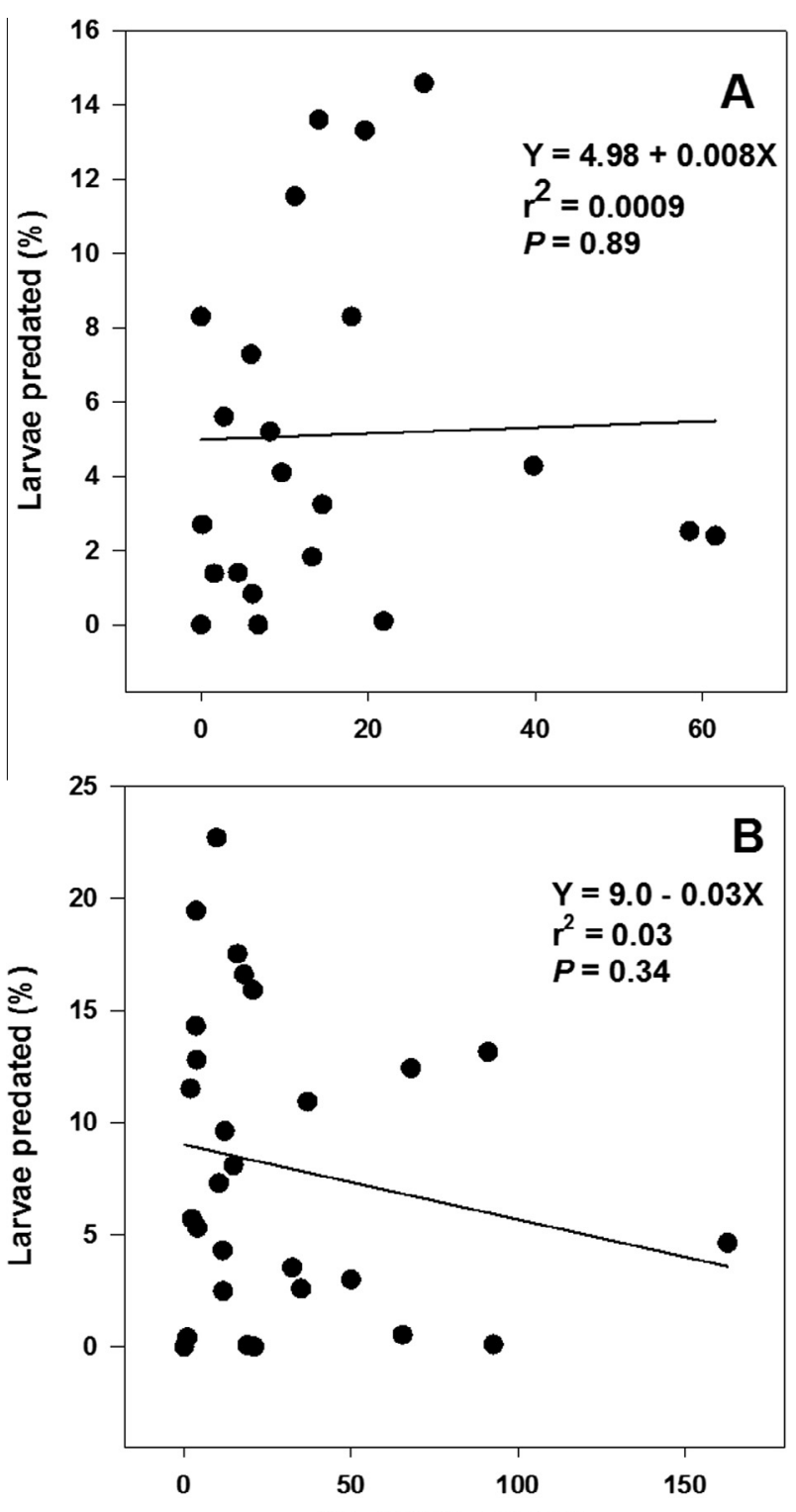

No. larvae per tree

Fig. 3. Relationship between the number of $O$. vitiosa larvae per tree and the percentage of $O$. vitiosa larvae predated in the first (A) and second (B) experiments.

\section{Discussion}

Symondson et al. (2002) found that predators with a wide host range were unlikely to show either an aggregative or a numerical response to any single prey species, unless that prey constitutes

Table 1

Pearson correlation coefficients for percent predation effects on plant variables.

\begin{tabular}{lllll}
\hline Experiment & Variable & $N$ & $r$ & $P$ \\
\hline 1 & Damage & 12 & -0.29 & 0.34 \\
MRGR leaf & 12 & 0.24 & 0.44 \\
& MRGR wood & 12 & -0.07 & 0.81 \\
MRGR height & 12 & -0.06 & 0.84 \\
& Seed & 12 & -0.11 & 0.71 \\
& Damage & 22 & -0.20 & 0.36 \\
& MRGR leaf & 21 & -0.06 & 0.80 \\
& MRGR wood & 21 & 0.35 & 0.11 \\
& MRGR height & 21 & 0.34 & 0.13 \\
& Seed & 21 & 0.38 & 0.08 \\
\hline
\end{tabular}



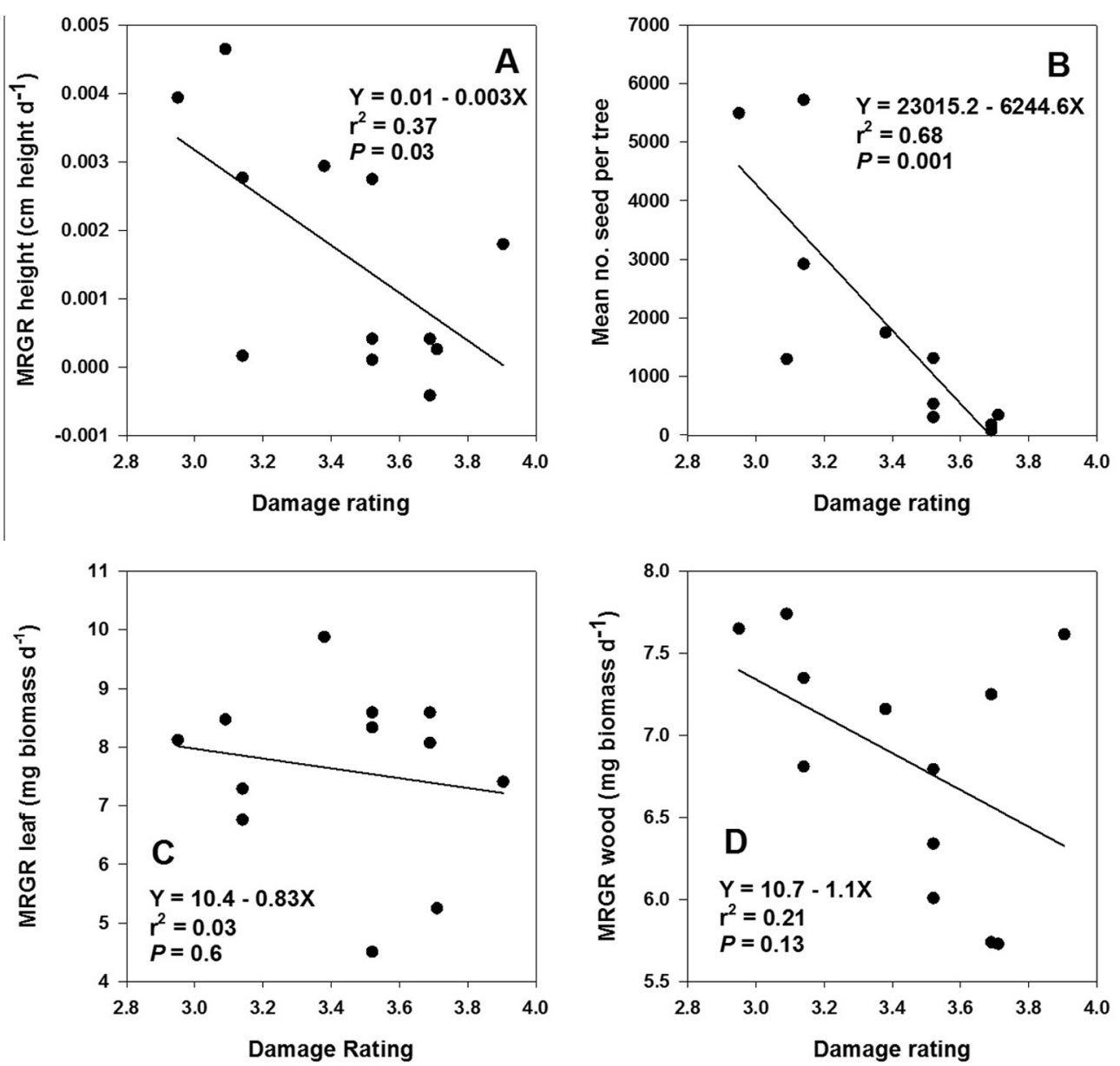

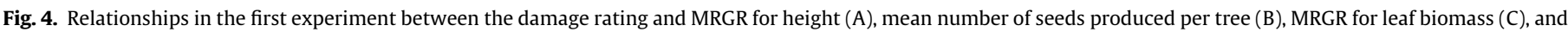
MRGR for woody biomass (D)

a major component of the total available prey. In certain areas, sustained outbreak densities of $O$. vitiosa are common and would constitute the most abundant prey item in a community dominated by M. quinquenervia. Christensen et al. (2011) cited a positive numerical response by $P$. mucronatus whereby more predators were noted with increasing density of larger 0 . vitiosa larvae. In the present study, predation outcomes were recorded rather than predator sightings which may explain why no analogous predator response was found. The congener $P$. maculiventris typically responded to increased prey densities with greater adult size and fecundity, increased nymphal survival, and shorter development times (Legaspi and O'Neil, 1994).

The lack of a predation response may also reflect the influence of intraguild predation and cannibalism which can have considerable effects on predator dynamics (Polis and Holt, 1992). Intraguild predation was present in up to $60 \%$ of trophic groupings in food webs and may weaken the effect of predation on herbivores as well as dampen the effect of trophic cascades on primary production (Arim and Marquet, 2004; Finke and Denno, 2004; van Veen Frank et al., 2006).

The influence of predation by $P$. mucronatus did not cascade down to the producer level as evidenced by a lack of impact on all plant parameters in both experiments. Thus, despite predation pressure, larval populations of 0 . vitiosa were always present and it was their continual defoliation of new growth that suppressed overall vegetative growth and seed production (Tipping et al., 2008). Evidence of the effectiveness of this agent is strong with multiple studies showing population level density declines of $M$. quinquenervia, increases in native plant abundance and diversity, and a reduced ability of the plant to re-invade habitats (Rayamajhi et al., 2009; Tipping et al., 2009; Tipping et al., 2012).

In general, $O$. vitiosa populations remained abundant throughout the duration of both experiments, thereby creating a stable resource that remained available to predators like $P$. mucronatus. This situation appears to represent the contemporary concern of critics whereby an abundant prey resource may promote apparent competition via another shared prey resource (Holt and Lawton, 1994). The only other potential prey of any abundance on this plant was Boreioglycaspis melaleucae Moore (Hemiptera: Psyllidae), which was also intentionally released as a biological control agent (Center et al., 2006). This species, however, is more seasonal than $O$. vitiosa and not as readily attacked by $P$. mucronatus adults or nymphs (P.W.T. unpublished data). Despite the relative continuous abundance of prey, there was no density-dependent response by predators and percent predation of 0 . vitiosa remained in single digits throughout the course of this study.

Since most cases of apparent competition are asymmetrical, one potential avenue for indirect effects would be 'spillover' of vagile $P$. mucronatus adults into other habitats (Chaneton and Bonsall, 2000). In order for this to occur the alternate prey would need to display partially overlapping temporal dynamics coupled by predator switching or dispersal across habitat patches and host plant species (Settle et al., 1996; Hanna et al., 1997). Predators like Podisus sp. that readily satiate (have low attack rates) pose less risk to 

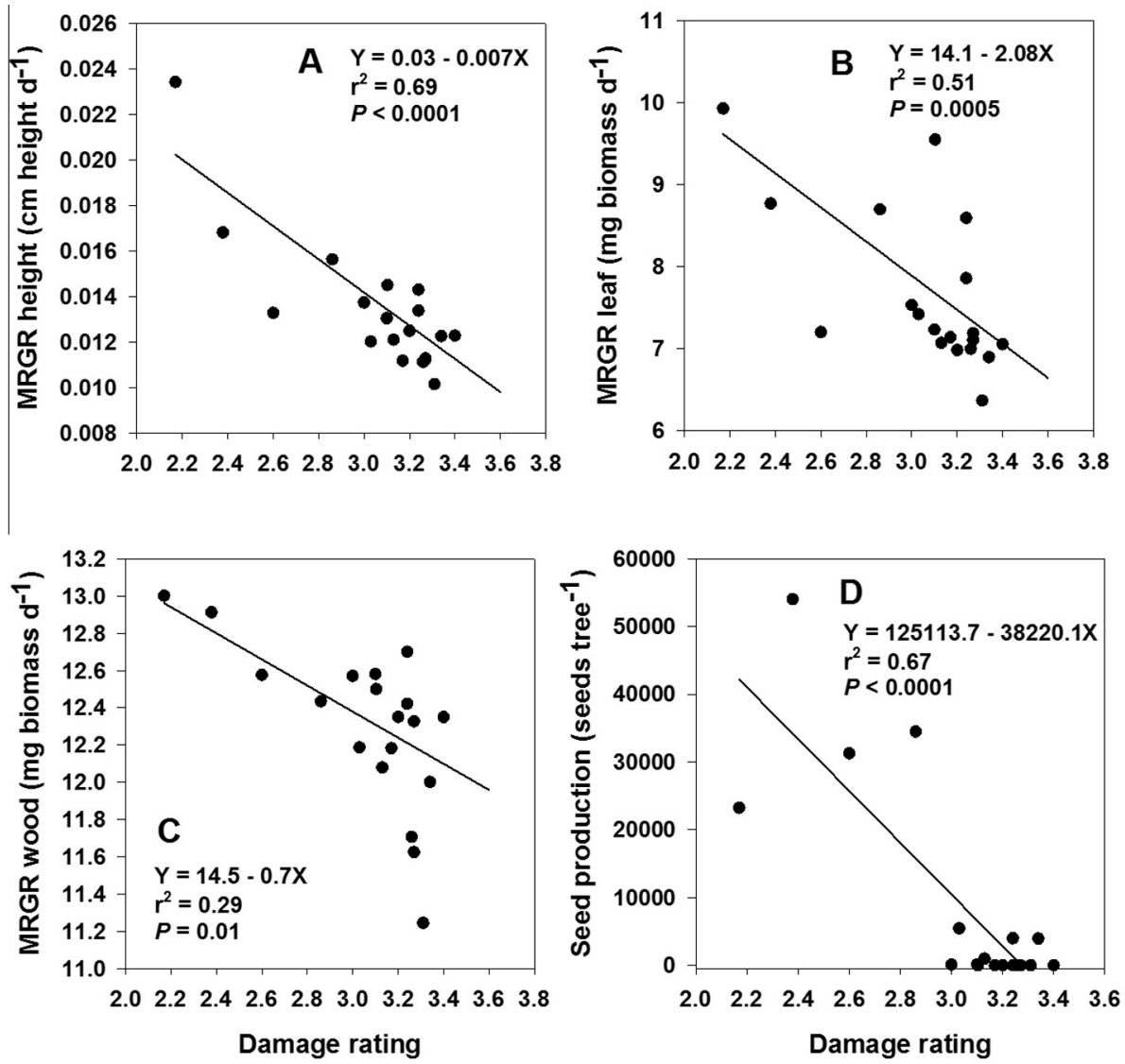

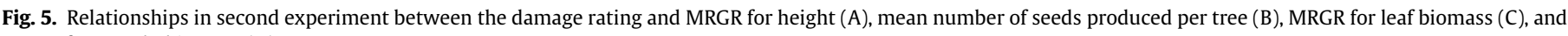
MRGR for woody biomass (D).

Table 2

Stepwise forward regression of plant variables on densities of large, small, and predated 0 . vitiosa larvae per tip from two experiments.

\begin{tabular}{|c|c|c|c|c|c|c|}
\hline Experiment $^{\mathrm{a}}$ & Dependent & Step & Independent & $r^{2}$ & $P$ & Slope \\
\hline 1 & MRGR leaf biomass $\left(\mathrm{mg} \mathrm{d}^{-1}\right)$ & 1 & Large larvae & 0.42 & 0.02 & -208.1 \\
\hline \multirow[t]{4}{*}{2} & Damage & 1 & Large larvae & 0.15 & 0.12 & 21.6 \\
\hline & MRGR leaf biomass $\left(\mathrm{mg} \mathrm{d}^{-1}\right)$ & 1 & Large larvae & 0.41 & 0.04 & -55.6 \\
\hline & & 2 & Small larvae & 0.43 & 0.06 & -88.9 \\
\hline & Seeds (No. tree ${ }^{-1}$ ) & 1 & Large larvae & 0.24 & 0.05 & -140197.0 \\
\hline
\end{tabular}

${ }^{\text {a }}$ Experiment number.

Table 3

Durbin-Watson statistics for autocorrelation analysis of live larvae and percent predation of 0 . vitios $a$ over two experiments.

\begin{tabular}{|c|c|c|c|c|c|}
\hline \multirow[t]{2}{*}{ Experiment } & \multirow[t]{2}{*}{ Variable } & \multicolumn{4}{|c|}{ Time lag } \\
\hline & & 1 & 2 & 3 & 4 \\
\hline \multirow[t]{2}{*}{1} & Live larvae & $1.58^{*}$ & $1.63^{*}$ & $1.68^{*}$ & $1.57^{*}$ \\
\hline & Dead larvae & 2.11 & 2.27 & 0.9 & 1.02 \\
\hline \multirow[t]{2}{*}{2} & Live larvae & $1.46^{*}$ & $1.76^{*}$ & $1.59^{*}$ & 1.72 \\
\hline & Dead larvae & 2.38 & 2.24 & 1.42 & 2.15 \\
\hline
\end{tabular}

* $p$ value of 0.01 for Durbin-Watson tests of positive autocorrelation over four time lags (sample periods).

non-targets which may instead experience indirect mutualisms rather than competition (Holt and Hochberg, 2001). The barriers to such subsidies can be considerable, consisting of both physical and functional factors that encompass geomorphology, vegetation structure and cover, and increased risk of predation (Cadenasso et al., 2004).

If longevity is one gauge of the relative importance of a predator subsidy, then it was negligible because the number of larvae killed 
by $P$. mucronatus was equally likely to be higher or lower between consecutive sample periods, despite strong positive trends in prey densities. The continued abundance of the agent serves to curtail the invasiveness of the weed despite the fact that densities of mature plants are largely unaffected. The chemical defenses utilized by 0 . vitiosa larvae protect it from most predators which, in turn, probably helps to limit its potential as a significant subsidy. This study provides a tailored counterpoint to the recent narrative that biological control agents that develop abundant populations, without directly reducing the target weed, are ineffective and will likely cause unpredictable and negative impacts to food webs.

\section{Acknowledgment}

We thank Laurie Bauer, Eileen Pokorny, Tracy Davern, Kirk Tonkel, Andrea Kraal, Matthew Smart, and Deah Leurance for their assistance in collecting and processing the data.

\section{References}

Arim, M., Marquet, P.A., 2004. Intraguild predation: a widespread interaction related to species biology. Ecol. Lett. 7, 557-564.

Bodle, J.M., Ferriter, A.P., Thayer, D.D., 1994. The biology, distribution, and ecological consequences of Melaleuca quinquenervia in the Everglades. In: Davis, S.M., Ogden, J.C. (Eds.), Everglades: The Ecosystem and its Restoration. St. Lucie Press, Delray Beach, USA, pp. 341-355.

Cadenasso, M.L., Pickett, S.T.A., Weathers, K.C., 2004. Effect of landscape boundaries on the flux of nutrients, detritus, and organisms. In: Polis, G.A., Power, M.E., Huxel, G.R. (Eds.), Food Webs at the Landscape Level. University of Chicago Press, Chicago, USA, pp. 154-168.

Carvalheiro, L.G., Buckley, Y.M., Ventim, R., Fowler, S.V., Memmott, J., 2008. Apparent competition can compromise the safety of highly specific biocontrol agents. Ecol. Lett. 11, 690-700.

Center, T.D., Van, T.K., Rayachhetry, M., Buckingham, G.R., Dray, F.A., Wineriter, S., Purcell, M., Pratt, P.D., 2000. Field colonization of the melaleuca snout beetle (Oxyops vitiosa) in south Florida. Biol. Control 19, 112-123.

Center, T.D., Pratt, P.D., Tipping, P.W., Rayamajhi, M.B., Van, T.K., Wineriter, S.A. Allen Dray Jr., F., Purcell Jr., M.F., 2006. Field colonization, population growth, and dispersal of Boreioglycaspis melaleucae Moore, a biological control agent of the invasive tree Melaleuca quinquenervia (Cav.) Blake. Biol. Control 39, 363374.

Center, T.D., Dray, F.A., 2010. Bottom-up control of water hyacinth weevil populations: do the plants regulate the insects? J. Appl. Ecol. 47, 329-337.

Chaneton, E.J., Bonsall, M.B., 2000. Enemy mediated apparent competition: empirical patterns and evidence. Oikos 88, 380-394.

Cloutier, C., Bauduin, F., 1995. Biological control of the Colorado potato beetle, Leptinotarsa decemlineata (Coleoptera: Chrysomelidae) in Quebec by augmentative releases of the two-spotted stinkbug Perillus bioculatus (Hemiptera: Pentatomidae). Can. Entomol. 127, 195-212.

Cohen, A.C., 1984. Food consumption, food utilization, and metabolic rates of Geocoris punctipes (Heteroptera: Lygaeidae) fed Heliothis virescens (Lepidoptera: Noctuidae) eggs. Entomophaga 29, 361-367.

Cohen, A.C., 1985. Metabolic rates of two hemipteran members of a predator-prey complex. Comp. Biochem. Physiol. 81A, 833-836.

Costello, S.L., Pratt, P.D., Rayachhetry, M.B., Center, T.D., 2002. Morphology and life history characteristics of Podisus mucronatus (Heteroptera: Pentatomidae). Florida Entomol. 85, 344-350.

Christensen, R.M., Pratt, P.D., Costello, S.L., Rayamajhi, M.B., Center, T.D., 2011. Acquired natural enemies of the weed biological control agent Oxyops vitiosa (Coleoptera: Curculionidae). Florida Entomol. 94, 1-8.

Dray, F.A., Bennett, B.C., Center, T.D., 2006. Invasion history of Melaleuca quinquenervia (Cav.) S.T. Blake in Florida. Castanea 71, 210-225.

Evans, H.F., 1976. The searching behaviour of Anthocorus confusus (Reuter) in relation to prey density and plant surface topography. Ecol. Entomol. 1, 163169.

Evans, E.W., 1982a. Feeding specialization in predatory insects: hunting and attack behavior of two stinkbug species (Hemiptera: Pentatomidae). Am. Mid. Nat. 108, 96-104.

Evans, E.W., 1982b. Timing of reproduction by predatory stinkbugs (Hemiptera: Pentatomidae): patterns and consequences for a generalist and a specialist. Ecology 63, 147-158.

Fagan, W.F., Hurd, L.E., 1994. Hatch density variation of a generalist arthropod predator: population consequences and community impact. Ecology 75, 20222032.

Fauvergue, X., Vercken, E., Malausa, T., Hufbauer, R.A., 2012. The biology of small, introduced populations, with special reference to biological control. Evol. Appl. $5,424-443$.

Finke, D.L., Denno, R.F., 2004. Predator diversity dampens trophic cascades. Nature 429, 407-410.
Freund, R.J., Wilson, W.J., 1998. Regression Analysis: Statistical Modeling of a Response Variable. Academic Press, San Diego, CA, USA.

Freund, R.J., Littell, R.C., 2000. SAS System for Regression, third ed. SAS Institute, Cary, NC, USA.

Garren, J.M., Strauss, S.Y., 2009. Population-level compensation by an invasive thistle thwarts biological control from seed predators. Ecol. Appl. 19, 709-721.

Julian, P., Everham, E.M., Main, M.B., 2012. Influence of a large-scale removal of an invasive plant (Melaleuca quinquenervia) on home-range size and habitat selection by female Florida panthers (Puma concolor coryi) with Big Cypress National Preserve, Florida. Southeast. Nat. 11, 337-348.

Hanna, R., Wilson, L.T., Zalom, F.G., Flaherty, D.L., 1997. Effects of predation and competition on the population dynamics of Tetranychus pacificus on grapevines. J. Appl. Ecol. 34, 878-888.

Headrick, D.H., Goeden, R.D., 2001. Biological control as a tool for ecosystem management. Biol. Control 21, 249-257.

Holt, R.D., Lawton, J.H., 1994. The ecological consequences of shared natural enemies. Ann. Rev. Ecol. System 25, 495-520.

Holt, R.D., Hochberg, M.E., 2001. Indirect interactions, community modules and biological control: a theoretical perspective. In: Wajnberg, E., Scott, J.K. Quimby, P.C. (Eds.), Evaluating Indirect Ecological Effects of Biological Control. CAB International, Wallingford, UK, pp. 13-37.

Kaufman, S.R., Smouse, P.E., 2001. Comparing indigenous and introduced populations of Melaleuca quinquenervia (Cav.) Blake: response of seedlings to water and pH levels. Oecologica 127, 487-494.

Kokkoris, G.D., Troumbis, A.Y., Lawton, J.H., 1999. Patterns of species interaction strength in assembled theoretical competition communities. Ecol. Lett. 2, 7074.

Laroche, F.B., 1998. Managing melaleuca (Melaleuca quinquenervia) in the Everglades. Weed Tech. 12, 726-732.

Legaspi, J.C., O'Neil, R.J., 1994. Developmental response of nymphs of Podisus maculiventris (Heteroptera: Pentatomidae) reared with low numbers of prey. Environ. Entomol. 23, 374-380.

Manrique, V., Diaz, R., Hight, S.D., Overholt, W.A., 2011. Evaluation of mortality factors using life table analysis of Gratiana boliviana, a biological control agent of tropical soda apple in Florida. Biol. Control 59, 354-360.

Martin, M.R., Tipping, P.W., Sickman, J.O., 2009. Invasion by an exotic tree alters above and belowground ecosystem components. Biol. Invasions 11, 1883-1894.

Martin, M.R., Tipping, P.W., Reddy, K.R., Daroub, S.H., Roberts, K.M., 2010 Interactions of biological and herbicidal management of Melaleuca quinquenervia with fire: consequences for ecosystem services. Biol. Control 54, 307-315.

Martin, M.R., Tipping, P.W., Reddy, K.R., Madeira, P.T., Fitzgerald, D., 2011. An evaluation of the impact of Melaleuca quinquenervia invasion and management on plant community structure after fire. Aquatic Bot. 95, 287-291.

Mc Fadyen, R.E.C., 1998. Biological control of weeds. Ann. Rev. Entomol. 43, 369 393.

McPherson, J.E., 1982. The Pentatomoidea (Hemptera) of Northeastern North America. Southern Illinois University Press, Carbondale, IL, USA.

Müller-Schärer, H., Schaffner, U., 2008. Classical biological control: exploiting enemy escape to manage plant invasions. Biol. Invasions 10, 859-874.

O'Hare, N.K., Dalrymple, G.H., 1997. Wildlife in southern Everglades wetlands invaded by Melaleuca (Melaleuca quinquenervia). Bull. Florida Mus. Nat. Hist. 41, $1-68$.

O'Neal, R.J., 1988. Predation by Podisus maculiventris (Say) on Mexican bean beetle, Epilachna varivestis Mulsant, in Indiana soybeans. Can. Entomol. 120, 161-166.

Paynter, Q., 2004. Evaluating Mimosa pigra biological control in Australia. In: Julien, M., Flanagan, G., Heard, T., Hennecke, B., Paynter, Q., Wilson, C. (Eds.), Research and Management of Mimosa pigra. CSIRO Entomology, Canberra, Australia, pp. $117-121$.

Paynter, Q., Fowler, S.V., Gourlay, A.H., Groenteman, R., Peterson, P.G., Smith, L. Winks, C.J., 2010. Predicting parasitoid accumulation on biological control agents of weeds. J. Appl. Ecol. 47, 575-582.

Pearson, D.E., Callaway, R.M., 2006. Biological control agents elevate hantavirus by subsidizing deer mouse populations. Ecol. Lett. 9, 443-450.

Polis, G.A., Holt, R.D., 1992. Intraguild predation: the dynamics of complex trophic interactions. Trends Ecol. Evol. 7, 151-154.

Polis, G.A., Strong, D.R., 1996. Food web complexity and community dynamics. Am. Nat. 147, 813-846.

Power, M.E., Tilman, D., Estes, J., Menge, B.A., Bond, W.J., Mills, L.S., Daily, G., Castilla, J.C., Lubchenco, J., Paine, R.T., 1996. Challenges in the quest for keystones. Bioscience 46, 609-620.

Purcell, M.F., Balciunas, J.K., 1994. Life history and distribution of the Australian weevil Oxyops vitiosa (Coleoptera: Curculionidae), a potential biological control agent for Melaleuca quinquenervia (Myrtaceae). Ann. Entomol. Soc. Am. 87, 867873.

Rayachhetry, M.B., Van, T.K., Center, T.D., Laroche, F., 2001. Dry weight estimation of the aboveground components of Melaleuca quinquenervia trees in southern Florida. Forest Ecol. Manage. 142, 281-290.

Rayachhetry, M.B., Van, T.K., Center, T.D., Goolsby, J.A., Pratt, P.D., Racelis, A., 2002 Biological attributes of the canopy-held Melaleuca quinquenervia seeds in Australia and Florida. J. Aquat. Plant Manage. 40, 87-91.

Rayamajhi, M.B., Pratt, P.D., Center, T.D., Tipping, P.W., Van, T.K., 2009. Decline in exotic tree density facilitates increased plant diversity: the experience from Melaleuca quinquenervia invaded wetlands. Wetlands Ecol. Manage. 17, 455467. 
SAS Institute, 1999. SAS/STAT User's Guide. SAS Institute, Cary, NC.

Settle, W.H.H., Ariawan, E.T., Astuti, W., Cahyana, A.L., Hakim, A.L., Hakim, D. Hindayana, A.S., Lestari, Pajarningsih, 1996. Managing tropical rice pest through conservation of generalist natural enemies and alternative prey. Ecology 77, $1975-1988$.

Symondson, W.O.C., Sunderland, K.D., Greenstone, M.H., 2002. Can generalist predators be effective biocontrol agents? Ann. Rev. Entomol. 47, 561-594.

Thomas, M.B., Reid, A.M., 2007. Are exotic natural enemies an effective way of controlling invasive plants? Trends Ecol. Evol. 22, 447-453.

Tipping, P.W., Martin, M.R., Pratt, P.D., Center, T.D., Rayamajhi, M.R., 2008. Suppression of growth and reproduction of an exotic invasive tree by two introduced insects. Biol. Control 44, 235-241.

Tipping, P.W., Martin, M.R., Nimmo, K.R., Pierce, R.M., Smart, M.D., White, E, Madeira, P.T., Center, T.D., 2009. Invasion of a West Everglades wetland by Melaleuca quinquenervia countered by classical biological control. Biol. Control 48, 73-78.

Tipping, P.W., Martin, M.R., Pierce, R.M., Center, T.D., Pratt, P.D., Rayamajhi, M.B., 2012. Post-biological control invasion trajectory for Melaleuca quinquenervia in a seasonally inundated wetland. Biol. Control 60, 163-168.

Van, T.K., Rayachhetry, M.B., Center, T.D., Pratt, P.D., 2002. Litter dynamics and phenology of Melaleuca quinquenervia in south Florida. J. Aquat. Plant Manage. $40,22-27$. van Veen Frank, F.J., Morris, R.J., Godfray, H.C.J., 2006. Apparent competition, quantitative food webs, and the structure of phytophagous insect communities. Annu. Rev. Entomol. 51, 187-208.

Veldtman, R., Lado, T.F., Botes, A., Proches, S., Timm, A.E., Geertsema, H., Chown, S.L., 2011. Creating novel food webs on introduced Australian acacias: indirect effects of galling biological control agents. Div. Distrib. 17, 958-967.

Warren, L.O., Wallis, G., 1971. Biology of the spined soldier bug Podisus maculiventris. J. Ga. Entomol. Soc. 6, 109-116.

Wheeler, G.S., Massey, L.M., Southwell, I.A., 2002. Antipredator defense of biological control agent Oxyops vitiosa is mediated by plant volatiles sequestered from the host plant Melaleuca quinquenervia. J. Chem. Ecol. 28, 297-315.

Wheeler, G.S., Massey, L.M. Southwell, I.A., 2003. Dietary influences on terpenoids sequestered by the biological control agent Oxyops vitiosa: effect of plant volatiles from different Melaleuca quinquenervia chemotypes and laboratory host species. J. Chem. Ecol. 29, 189-208.

Wiedenmann, R.N., O’Neil, R.J., 1991. Searching behavior and time budgets of the predator Podisus maculiventris. Entomol. Exp. Appl. 60, 83-93.

Willis, A.J., Memmott, J., 2005. The potential for indirect effects between a weed, one of its biocontrol agents and native herbivores: a food web approach. Biol. Control 35, 299-306.

Yodzis, P., 1988. The indeterminacy of ecological interactions as perceived through perturbation experiments. Ecology 69, 508-515. 